\title{
Pseudointernuclear ophthalmoplegia as a presenting feature of ocular myasthenia gravis
}

\author{
Britta Nijsse, ${ }^{1}$ Marijke Wefers Bettink, ${ }^{2}$ Rinze F Neuteboom ${ }^{1}$
}

${ }^{1}$ Department of Neurology, Erasmus Medical Center, Rotterdam, The Netherlands 2Department of Ophthalmology, Rotterdam Eye Hospital, Rotterdam,

The Netherlands

\section{Correspondence to}

Britta Nijsse,

b.nijsse@elisabeth.nl

Accepted 25 May 2014
CrossMark

To cite: Nijsse $B$, Wefers Bettink M, Neuteboom RF. BMJ Case Rep Published online: [please include Day Month Year] doi:10.1136/ bcr-2013-203234

\section{DESCRIPTION}

A 16-year-old girl presented with fluctuating diplopia, ptosis of the left eye and an internuclear ophthalmoplegia (INO; video 1), which resolved after administration of neostigmine. Antiacetylcholine receptor antibodies were present in the serum: $0.34 \mathrm{nmol} / \mathrm{L}$ (normal range $0-0.25 \mathrm{nmol} / \mathrm{L}$ ). These findings led to the diagnosis of ocular myasthenia.

INO is mostly seen with lesions of the medial longitudinal fasciculus in the dorsomedial brainstem tegmentum of either the pons or the midbrain, causing adduction weakness of the ipsilateral eye and a contralateral abduction nystagmus. The underlying mechanisms causing abduction nystagmus are not fully understood. Probably, it reflects an adaptive process that helps to overcome the adduction weakness of the opposite eye. ${ }^{1}$ This is consistent with Hering's law of equal innervation, which states that increased innervation to a weak muscle in one eye is accompanied by a commensurate increase in innervation to the yoke muscle in the other eye.

In myasthenia gravis (MG), extraocular muscle weakness can cause the same oculomotor pattern as in INO. ${ }^{2}$ However, in such cases there is no lesion in the central nervous system and therefore it has

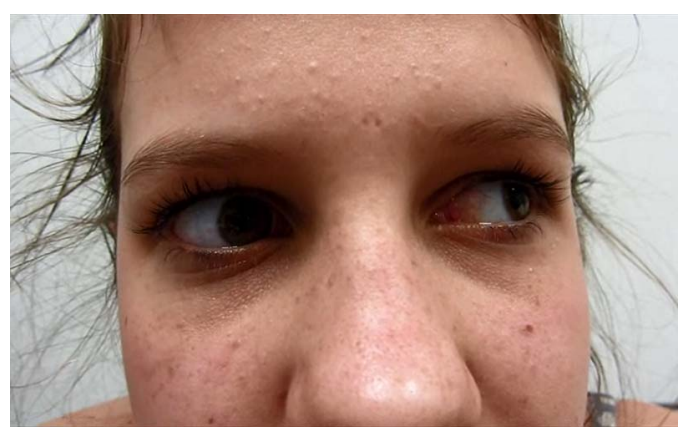

Video 1 Nystagmus of the abducting left eye and impaired adduction of the right eye, representing a pseudo-internuclear ophthalmoplegia (pseudo-INO) in a patient with ocular myasthenia gravis. Also note the slight ptosis of the left eye. been referred to as pseudo-INO. In MG, there is intermittent block of neuromuscular conduction to extraocular muscles, which causes muscle weakness. Although the adduction weakness has a different cause as in INO, the assumed pathogenetic mechanism of the abduction nystagmus in pseudo-INO is the same. ${ }^{3}$ Pseudo-INO can also be a clinical manifestation of Guillain-Barré syndrome (GBS) or the Miller-Fisher variant of GBS. ${ }^{3}$

The symptoms in our patient completely resolved rapidly after treatment with low doses of pyridostigmine (30 $\mathrm{mg}$ four times a day).

\section{Learning points}

- In any patient with an internuclear ophthalmoplegia (INO) which can not be explained by a lesion in the brainstem, consider pseudo-INO.

- In the case of pseudo-INO, it is important to perform additional tests on diagnosing myasthenia gravis.

Contributors BN contributed by drafting the manuscript for intellectual content, including medical writing. MWB contributed by revising the manuscript, including medical writing. RN contributed by revising the manuscript, including medical writing and diagnosis on our patient.

Competing interests None.

Patient consent Obtained.

Provenance and peer review Not commissioned; externally peer reviewed.

\section{REFERENCES}

1 Zee DS, Hain TC, Carl JR. Abduction nystagmus in internuclear ophthalmoplegia. Ann Neurol 1987;21:383.

2 Glaser JS. Myasthenic pseudo-internuclear ophthalmoplegia. Arch Ophthalmol 1966;75:363-6.

3 Feldon SE, Stark L, Lehman SL, et al. Oculomotor effects of intermittent conduction block in myasthenia gravis and Guillain-Barre syndrome. An oculographic study with computer simulations Arch Neurol 1982;39:497-503. 


\section{Images in...}

Copyright 2014 BMJ Publishing Group. All rights reserved. For permission to reuse any of this content visit http://group.bmj.com/group/rights-licensing/permissions.

BMJ Case Report Fellows may re-use this article for personal use and teaching without any further permission.

Become a Fellow of BMJ Case Reports today and you can:

- Submit as many cases as you like

- Enjoy fast sympathetic peer review and rapid publication of accepted articles

- Access all the published articles

- Re-use any of the published material for personal use and teaching without further permission

For information on Institutional Fellowships contact consortiasales@bmjgroup.com

Visit casereports.bmj.com for more articles like this and to become a Fellow 